\title{
VIABILITY AND GENE TRANSCRIPTION OF Campylobacter jejuni IN INFANT MILK FORMULAS
}

\author{
VIABILIDADE E TRANSCRIÇÃO GENÉTICA DE Campylobacter jejuni EM \\ FÓRMULAS LÁCTEAS INFANTIS
}

\author{
Roberta Torres de MELO'; ${ }^{1}$ Carla Ribeiro PACHECO'; Guilherme Paz MONTEIRO'; \\ Yara Cristina Paiva MAIA ${ }^{2}$; Eliane Pereira MENDONÇA ${ }^{3}$; Raquelline Figueiredo Braz ${ }^{1}$; \\ Edson Campos VALADARES JÚNIOR ${ }^{1}$; Daise Aparecida ROSSI ${ }^{1}$ \\ 1. Laboratório de Biotecnologia Animal Aplicada, Faculdade de Medicina Veterinária, Universidade Federal de Uberlândia - \\ UFU, Uberlândia, MG, Brasil. roberta-melo@hotmail.com; 2. Curso de Nutrição, Faculdade de Medicina - UFU, Uberlândia, \\ MG, Brasil; 3. Laboratório de Biologia Molecular, Faculdade de Medicina Veterinária, Universidade de Uberaba - UNIUBE, \\ Uberlândia, MG, Brasil.
}

\begin{abstract}
This study simulated the contamination of two varieties of infant milk formulas (homemade and commercial) with $10^{3}$ and $10^{4} \mathrm{CFU} / \mathrm{mL}$ of Campylobacter jejuni, that were kept under refrigeration $\left(4-7^{\circ} \mathrm{C}\right)$ for up to 48 hours. The aim of this study was to verify the maintenance of the viability and ability of Campylobacter jejuni to produce transcripts of virulence and resistance to stress conditions during periods of 0 (after preparation), 24 and 48 hours. $C$. jejuni remained viable during all analyzed stages and the presence of coliforms was not detected. In general, the counts reduced $1 \mathrm{log}$ cycle after 48 hours for all samples, except the $10^{4} \mathrm{CFU} / \mathrm{mL}$ inoculum of commercial formula, which reduced 2 log cycles, indicating greater injury of $C$. jejuni in this food matrix. $C$. jejuni showed to be more adapted to homemade matrix, due to high transcription of the gene related to cell invasion, $c i a B$, and more susceptible in the commercial matrix, due to the high transcription of genes related to conditions of stress tolerance $(d n a J, p 19, \operatorname{sodB})$. The low infective dose of $C$. jejuni coupled with greater vulnerability of children less than five years indicate the need for care in the preparation and maintenance of infant formulas, to prevent the use of contaminated raw material and crosscontamination, especially in homemade formulations.
\end{abstract}

KEYWORDS: Campylobacteriosis. Infants. Gastroenteritis.

\section{INTRODUCTION}

The control of food quality is primordial to reduce the risks of population to get infected through food consumption. Among foodborne pathogens, stands out the bacteria of Campylobacter genus (GODOI et al., 2010)

Campylobacter jejuni is the most commonly species associated with human cases of foodborne infections (EFSA, 2013). This is the most isolated microorganism in patients with foodborne infection, exceeding about three to four times other enteropathogens such as Salmonella or Escherichia coli (WHO, 2012). Campylobacteriosis can cause severe diarrhea with mucus or blood, fever, abdominal pain, nausea, vomiting, headache and muscle aches. Although, in most cases, the infection is limited to the signs and symptoms of gastroenteric infection, there may be complications such as meningitis, recurrent colitis, acute cholecystitis and Guillain Barré syndrome (ESTEVES et al., 2011).

Campylobacter can easily contaminate food, including meat, milk and milk products. Cases of campylobacteriosis in humans are usually associated with contact with domestic birds and pets, beyond the consumption of poultry meat and untreated water. Cross-contamination during food preparation in homes has also been described as an important route of transmission (EFSA, 2013).

In Brazil, the occurrence of Campylobacter in foods is still underestimated. Microbiological analysis for this microorganism is not routinely performed in cases of food poisoning (CARDOSO, 2009) and is not covered by existing legislation for both milk-based formulas as for other foods (BRASIL, 2001). The resolution $\mathrm{n}^{\circ} 12$ of January $2^{\text {nd }}, 2001$, of ANVISA (Agência Nacional de Vigilância Sanitária) only cites this microorganism as a pathogen (BRASIL, 2001).

Cross-contamination in homes is particularly important, since Campylobacter can be transferred between food by the hands or utensils (EFSA, 2013). Thus, the preparation of infant formula in places where there is presence of animal products may favor contamination by the handler. Moreover, the refrigerated storage with other raw foods or unprotected also features a procedure that 
can facilitate cross-contamination of infant formulas (LINHARES, 2012).

Infants have high immunological vulnerability and an immature digestive system (MAHAN and ESCOTT-STUMP, 2010). For these reasons, the feed of these individuals requires greater hygiene and health care, as in the manufacturing as in the handling and storage of food, particularly in the preparation of infant milk formula served in nursing bottles or cups.

Whereas children, especially those under five years old are more susceptible to campylobacteriosis (SILVA et al., 2007) and the risk of Campylobacter contamination during preparation and storage of the formulations, the present study aims to investigate the viability of $C$. jejuni and also to determine the ability to produce transcripts of virulence and resistance to stress conditions in infant milk formulas.

\section{MATERIAL AND METHODS}

\section{Study design}

We used two varieties of milk formula (homemade - originated from popular recipe based on corn starch - and commercial) prepared in domestic conditions, by boiling. The samples were experimentally contaminated with $10^{3}$ and $10^{4}$ $\mathrm{CFU} / \mathrm{mL}$ of Campylobacter jejuni and stored under refrigeration at a temperature $4-7^{\circ} \mathrm{C}$ for up to 48 hours. As a negative control we used uninoculated formulas stored under the same conditions.

Immediately after preparation (0 hours), 24 and 48 hours of storage, the samples were evaluated for the viability and capacity of transcripts production by microorganism.

Three replicates were performed on different days, with 18 analyzes for each formula, totaling 36 samples evaluated. All procedures were performed in triplicate.

\section{Preparation of infant milk formulas}

Two kinds of formulations were tested: one industrializated powder and other homemade recipe. The preparation of them was similar to a real situation of preparation/handling in domestic environment. For the present study it was necessary validation in laboratory.

The commercial formula used in the study is a product in powder, classified as a formula for specific follow-up to the infant in tenth month of life, containing prebiotics in concentration of 0.8 g/100mL, DHA (omega 3), lactose, vegetable oils (palm oil, canola oil, coconut oil, sunflower oil), maltodextrin, whey protein from milk, galactooligosaccharides, fructo-oligosaccharide, glucose syrup, calcium carbonate, fish oil, vitamin $\mathrm{C}$, iron sulphate, caseinate calcium, inositol, zinc sulfate, tocopherol, dibasic potassium phosphate, Lcarnitine, cupric gluconate, calcium phosphate, calcium d-pantothenate, nicotinamide, ascorbyl palmitate, vitamin $\mathrm{A}$, vitamin $\mathrm{E}$, vitamin $\mathrm{B} 1$, vitamin D6, manganese sulfate, vitamin B2, potassium iodide, folic acid, vitamin $\mathrm{K}$, sodium selenite, vitamin D3, biotin, lecithin emulsifiers, mono and diglycerides, flavorings.

The method to prepare the commercial formula was in accordance with the information stated on the label by the manufacturer. First, the potable and filtered water was boiled for five minutes and cooled for 30 minutes at room temperature. The standard dilution of $15 \%$ reported by the manufacturer indicates the addition of a measuring spoon for powder formula for each 30 $\mathrm{mL}$ of warm boiled water. Therefore, to $100 \mathrm{~mL}$ of warm water were used 15.4 grams of infant milk formula.

In order to prepare the homemade formula, also called infant pap or porridge, we proceeded to standardize the following ingredients: per $100 \mathrm{~mL}$ of pasteurized milk, boiled and cooled at room temperature, was used three grams of corn starch and five grams of granulated sugar. This formula was cooked to boiling point for more 10 minutes to get a creamy consistency, to simulate the domestic conditions.

\section{Experimental inoculation}

The study was conducted at the Laboratório de Biotecnologia Animal Aplicada, Universidade Federal de Uberlândia. For experimental inoculation a standard strain of $C$. jejuni NCTC 11351 (MicroBioLogics $®$ ) was used, in first peal after the acquisition.

The reactivation of the standard strain was performed as described by the supplier, which was plated on agar Campylobacter Blood- Free Selective Medium (m-CCDA) (Oxoid®). The pure and isolated colonies on agar were transferred to tubes containing $10 \mathrm{~mL}$ of $0.85 \% \mathrm{NaCl}$ sterile solution (Synth ${ }^{\circledR}$ ) and submitted to serial dilutions to determine the concentration of the inoculum.

Aliquots of $1 \mathrm{~mL}$ of saline containing $C$. jejuni were inoculated in infant milk formulas, to standardize the contamination of $10^{3}$ and $10^{4}$ $\mathrm{CFU} / \mathrm{mL}$. After inoculation, the formulations were immediately analyzed $(0 \mathrm{~h})$ and stored in a domestic refrigerator at a temperature of 4 to $7^{\circ} \mathrm{C}$, and then evaluated after 24 and 48 hours. 
The control groups were inoculated with $1 \mathrm{~mL}$ of $0.85 \% \mathrm{NaCl}$ sterile solution (Synth ${ }^{\circledR}$ ) and after they were kept under the same conditions of the tested groups, and evaluated at the same periods.

\section{Microbiological analysis}

The counting of Campylobacter was carried out using the technique recommended by ISO 10272-18 (2006), using the Campylobacter selective agar, Blood-Free Selective Agar Base - m-CCDA (OXOID $®)$.

Quantification of mesophilic heterotrophic bacteria was performed by the pour plate method, using Plate Count Agar (PCA) $\left(\right.$ Difco $^{\mathrm{TM}}$ ). For quantification of total and thermotolerant coliforms the most probable number (MPN) technique was used with pre-enrichment in Sodium Lauryl Sulfate broth (Difco ${ }^{\mathrm{TM}}$ ) and confirmation in Brilliant Green Bile Lactose and EC broths $\left(\right.$ Difco $\left.^{\mathrm{TM}}\right)$. The procedures were performed as recommended by Silva et al. (2007).

\section{Confirmation and rna extraction}

The confirmation of isolates as $C$. jejuni species was performed by PCR-multiplex, according to the technique described by Harmon et al. (1997).

RNA extraction was performed according to Li et al. (2008), with modifications proposed by Melo, 2013. The isolates from each sample were peaked to four other CCDA agar plates in order to obtain enough bacteria to do the RNA extraction, and then all of this cultivation was transferred to microcentrifuge tubes containing $2 \mathrm{~mL}$ of $0.85 \%$ $\mathrm{NaCl}$ solution (Synth $\left.{ }^{\circledR}\right)$. The mixture was centrifuged at $12,000 \mathrm{~g}$ for ten minutes at $4{ }^{\circ} \mathrm{C}$. To the formed pellet was added $1 \mathrm{~mL}$ of Trizol (Invitrogen $\AA$ ) and homogenized by vortexing (Phoenix ${ }^{\circledR}$ ). Then, $200 \mu \mathrm{L}$ of chloroform was added (Isofar®), and the procedure of homogenization was repeated by vortexing followed by centrifugation at $12,000 \mathrm{~g}$ for 15 minutes at $4{ }^{\circ} \mathrm{C}$.
The aqueous portion was transferred to a new microtube, which was added with $500 \mu \mathrm{L}$ of isopropanol (Sigma Aldrich ${ }^{\circledR}$ ), again homogenized and centrifuged at $12,000 \mathrm{~g}$ for 10 minutes at $4{ }^{\circ} \mathrm{C}$. At the formed pellet was added $1 \mathrm{~mL}$ of ethanol $75 \%$ (Sigma-Aldrich ${ }^{\circledR}$ ) and after homogenization and centrifugation at 7,500g for 5 minutes at $4{ }^{\circ} \mathrm{C}$, the supernatant was discarded. RNA pellets were dried at room temperature to be diluted in $20 \mu \mathrm{L}$ of DEPC water (Invitrogen $\left.{ }^{\circledR}\right)$. The quantification of RNA was performed in Nanodrop spectrophotometer (Thermo Scientific $\left.{ }^{\circledR}\right)$.

\section{Reverse transcription}

The reverse transcription polymerase chain reaction (RT-PCR) was used to evaluate the production of transcripts, as recommended by $\mathrm{Li}$ et al. (2008). For each sample it was used the following steps: $1 \mu \mathrm{g}$ of total RNA (200ng/uL), $10 \mathrm{U}$ of RNase inhibitor, $40 \mathrm{U}$ of MMLV-RT (Amersham Biosciences $\left.{ }^{\circledR}\right), \quad 1 \mathrm{X}$ of MMLV-RT buffer (Amersham Biosciences ${ }^{\circledR}$ ), $200 \mu \mathrm{M}$ of dNTP (dGTP, dATP, dCTP and dTTP), 126 pmoles of hexamer oligonucleotides as random primers (Invitrogen $\AA$ ) and $20 \mu \mathrm{L}$ of DEPC water (Invitrogen $®$ ). The solution was placed in microfuge at $37{ }^{\circ} \mathrm{C}$ for one hour to obtain the cDNA.

Subsequently $3 \mu \mathrm{L}$ of cDNA was used for amplification reaction of $25 \mu \mathrm{L}$, composed of $0.625 \mathrm{U}$ of Taq DNA polymerase, $5 \mathrm{mM}$ of $\mathrm{MgCl}_{2}$, $200 \mathrm{mM}$ of dNTPs and 4 pmoles of each primer (Invitrogen $\AA$ ). The positive control, $C$. jejuni NCTC 11351, and the negative control, consisting of sterile ultrapure water, were used in all amplification reactions.

The primers used to determine gene transcription were: $c i a B$ (invasion), dnaJ (thermotolerance), $p 19$ (iron transport during stress) and $\operatorname{sod} B$ (defense to oxidative stress), as shown in Table 1 . The $C$. jejuni strain NCTC 11351 shows all these genes in its genome (MELO et al., 2013).

Table 1. Primers used to verify the production of transcripts $\operatorname{ciaB}, d n a J, p 19$ and $\operatorname{sodB}$ gene for $C$. jejuni.

\begin{tabular}{llll}
\hline Genes & Sequence 5' $\rightarrow \mathbf{3}$, & Molecular weight (bp) & Reference \\
\hline ciaB & ATATTTGCTAGCAGCGAAGAG & 157 & Li et al. (2008) \\
& GATGTCCCACTTGTAAAGGTG & & \\
dnaJ & AGTGTCGAGCTTAATATCCC & 117 & Li et al. (2008) \\
& GGCGATGATCTTAACATACA & & \\
p19 & GATGATGGTCCTCACTATGG & 206 & Birk et al. (2012) \\
& CATTTTGGCGTGCCTGTGTA & & Birk et al. (2012) \\
& $\begin{array}{l}\text { TATCAAAACTTCAAATGGGG } \\
\text { TTTTCTAAAGATCCAAATTCT }\end{array}$ & & \\
\hline
\end{tabular}


Amplification was performed in thermocycler, according to cycles: 1 initial cycle at $94{ }^{\circ} \mathrm{C}$ for 3 minutes; 45 cycles of amplification in three stages: denaturation at $94{ }^{\circ} \mathrm{C}$ for 15 seconds, annealing at $51{ }^{\circ} \mathrm{C}$ for 20 seconds and extension at $72{ }^{\circ} \mathrm{C}$ for 20 seconds; completing with one more final cycle of extension at $72{ }^{\circ} \mathrm{C}$ for 3 minutes.

The separation of the amplified products was performed by electrophoresis on $1.5 \%$ agarose gel (Affymetrix ${ }^{\circledR}$ ), using the TBE $0.5 \mathrm{X}$ buffer (Invitrogen ${ }^{\circledR}$ ) and as a molecular weight standard the 50bp marker (Invitrogen ${ }^{\circledR}$ ).

\section{Statistical analysis}

The results obtained in triplicate analyzes were tabulated and submitted to descriptive statistics to calculate the percentages for the viability of $C$. jejuni and production of transcripts by isolates recovered from formulas in the three periods of cold storage and in three replications. Student's $\mathrm{T}$ and Mann-Whitney tests were used to evaluate differences in counts obtained over time, and Paired $\mathrm{T}$ test and Wilcoxon test to identify differences in transcript production, using the Graph Pad Prism 7.0 program.

\section{RESULTS AND DISCUSSION}

\section{Bioindicators}

In both formulas, in all analyzed samples, no total and thermotolerant coliform were detected.
The mesophilic heterotrophic bacteria had counts less than $1.0 \times 10^{1} \mathrm{CFU} \cdot \mathrm{mL}^{-1}$. These results show compliance with the standards established by the Codex Alimentarius, equivalent to a limit of $3 \mathrm{MPN}$ of coliforms and mesophilic bacteria equal to 1.0 $\times 10^{3}$ CFU. $\mathrm{mL}^{-1}$ (BRASIL, 2001; WHO, 2004). The low scores found for biomarkers microorganisms are related to the use of method of cooking in preparation of formulations. Similar results were found by Linhares (2012), who obtained counts less than $1.0 \times 10^{2}$ CFU.mL $\mathrm{mL}^{-1}$ for mesophilic in two infant milk formulas prepared in lacteries in Belo Horizonte, Minas Gerais, Brazil. The author also associated the lower counts with appropriate handling procedures.

Trindade (2009), found, in an analysis of formulas prepared in lactary, counts higher than that obtained in this work. Assunção (2008) also found samples with counts up to $1.0 \times 10^{6}$ CFU.mL ${ }^{-1}$ in Lisboa, Portugal. Both authors noted that formulas that require more handling time also had higher initial aerobic mesophilic bacteria counts, and after 24 hours of cooling, there is an increase in the count of these bacteria.

\section{Viability of Campylobacter jejuni}

The results show that $C$. jejuni remained viable and culturable during all stages of the experiment (Table 2).

Table 2. Mean counts of $C$. jejuni $\left(\mathrm{CFU} \cdot \mathrm{mL}^{-1}\right)$ in infant milk formulas experimentally contaminated after storage at $4-7^{\circ} \mathrm{C}$ for 0,24 and 48 hours.

\begin{tabular}{|c|c|c|c|c|c|c|c|c|}
\hline \multirow{3}{*}{ Milk Formula } & \multirow{3}{*}{ Hour } & \multicolumn{7}{|c|}{ Counts $($ CFU/mL)* } \\
\hline & & \multirow{2}{*}{ Control } & \multicolumn{2}{|c|}{ Inoculum $\mathbf{1 0}^{3}$} & \multicolumn{4}{|c|}{ Inoculum $10^{4}$} \\
\hline & & & Rep.1 & Rep.2 & Rep.3 & Rep.1 & Rep.2 & Rep.3 \\
\hline \multirow[t]{3}{*}{ Homemade } & 0 & 0 & $1,3 \times 10^{3}$ & $9,8 \times 10^{2}$ & $1,8 \times 10^{3}$ & $2,4 \times 10^{3}$ & $2,2 \times 10^{3}$ & $6,1 \times 10^{3}$ \\
\hline & 24 & 0 & $8,0 \times 10^{1}$ & $9,0 \times 10^{1}$ & $7,0 \times 10^{1}$ & $4,6 \times 10^{2}$ & $1,5 \times 10^{2}$ & $1,8 \times 10^{2}$ \\
\hline & 48 & 0 & $1,0 \times 10^{1}$ & $2,0 \times 10^{1}$ & $9,0 \times 10^{1}$ & $1,7 \times 10^{2}$ & $1,9 \times 10^{2}$ & $3,9 \times 10^{2}$ \\
\hline \multirow[t]{3}{*}{ Commercial } & 0 & 0 & $9,6 \times 10^{2}$ & $8,8 \times 10^{2}$ & $8,4 \times 10^{2}$ & $2,1 \times 10^{3}$ & $3,4 \times 10^{3}$ & $2,0 \times 10^{3}$ \\
\hline & 24 & 0 & $6,0 \times 10^{1}$ & $1,0 \times 10^{2}$ & $1,1 \times 10^{2}$ & $8,8 \times 10^{2}$ & $1,2 \times 10^{2}$ & $1,4 \times 10^{2}$ \\
\hline & 48 & 0 & $3,0 \times 10^{1}$ & $3,0 \times 10^{1}$ & $5,0 \times 10^{1}$ & $1,0 \times 10^{2}$ & $4,0 \times 10^{1}$ & $1,0 \times 10^{1}$ \\
\hline
\end{tabular}

Rep.: repetition; * The average results of triplicate analysis.

The low counts of biomarkers, which could compete with $C$. jejuni for nutrients, may have contributed to the agent survival, since, according Muraoka and Zhang (2011), the mechanisms of competitive exclusion influences directly in the presence of Campylobacter, which is considered a fragile and bad competitor.

Moreover, it can be inferred that the bacterium has developed devices that aided in their survival under injury conditions, in that case, the cold stress. Garénaux et al. (2008) have shown that Campylobacter provides an effective response to adapt to stress situations, which can allow its survival in adverse conditions, such as variations in temperature and other harsh environments.

Due to the low number of biomarkers in formulas, it was not possible to assess their influence on survival or reduction in Campylobacter 
counts. The influence of the microbiota naturally presented in foods should be better investigated in other studies, since that despite Muraoka and Zhang (2011) claims that Campylobacter veiculated by raw milk consumption is involved in several outbreaks in American states where the commercialization is allowed. Probably the unpasteurized milk has an endogenous microbiota and some level of subsequent contamination, regardless of hygiene practices applied during milking and packaging, and even under these conditions, Campylobacter can survive and infect consumers.

The counts of $C$. jejuni decresed in both formulations, with a mean reduction of $1 \mathrm{log}$ cycle in time zero to 24 hours $\left(\mathrm{p}=0,002-10^{3}\right.$ inoculum; $\mathrm{p}<0,0001-10^{4}$ inoculum), keeping constant after this period ( $\mathrm{p}=0,171-10^{3}$ inoculum, $\mathrm{p}=0,151-10^{4}$ inoculum) (Figure 1).

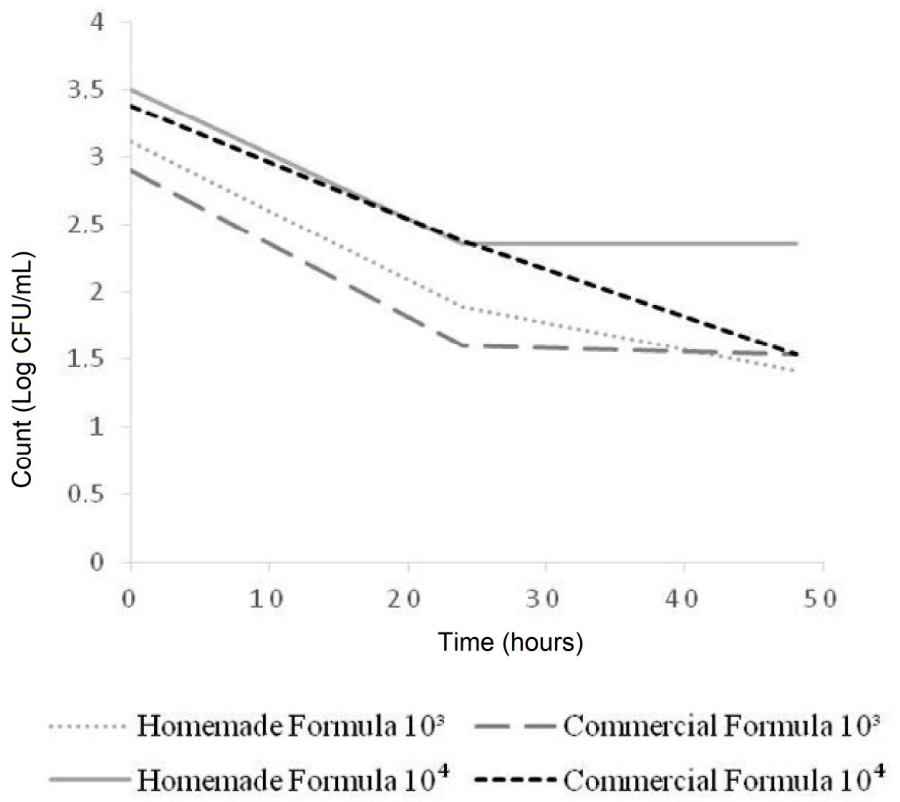

Figure 1. Mean counts of $C$. jejuni during storage at $4-7^{\circ} \mathrm{C}$ in homemade and commercial infant milk formulas artificially contaminated with $10^{3}$ and $10^{4} \mathrm{CFU} \cdot \mathrm{mL}^{-1}$.

It is important to reinforce that for the commercial formula inoculated with $10^{4} \mathrm{CFU} / \mathrm{mL}$ of C. jejuni had a mean reduction of 2 log cycles during the 48 hour period. These findings are in agreement with several previous studies showing that the number of viable $C$. jejuni cells is reduced when kept at $4{ }^{\circ} \mathrm{C}$ (EIDEH and AL-QADIRI, 2011; EL-SHIBINY et al., 2009; HADDAD et al., 2009). This decrease is associated with the fact that several biological activities are compromised in these conditions, including protein synthesis, oxygen consumption, catalase activity, ATP generation and motility (HADDAD et al., 2009).

Despite the reduction in cell number of $C$. jejuni, we can infer that the consumption of formulas stored under refrigeration for up to 48 hours can be a risk of infection to children, since the minimum infectious dose is very low, being less than $5.0 \times 10^{2} \mathrm{CFU} / \mathrm{mL}$ (IVANOVIC, 2012).

These results are similar to those obtained by Monteiro (2015), which examined the viability of Campylobacter in different types of milk and concluded that the microorganism is able to survive in this food matrix in sufficient numbers to cause infection.

The permanence of the agent in infant milk formulas shows that cross-contamination during the preparation of these foods in home can be an important way of Campylobacter transmission. Thus, handling, improper storage, the risk of crosscontamination in the home environment and the fact of the milk (used in the preparation of formulations) is a nutrient medium for the maintenance of pathogens such as Campylobacter spp. create conditions that allow the presence of this microorganism in milk formulas (CIDCN, 2014; EFSA, 2013; LINHARES, 2012; MADALOZZO et al., 2007). Allied to this, it is important to emphasize the greater susceptibility to campylobacteriosis in children less than five years, in which the infection can cause complications, including serious diseases such as Guillain Barré Syndrome (CIDCN, 2014; ESTEVES et al., 2011).

Therefore, it becomes essential to adopt measures of good practice in order to reduce the risks during the process of pre and post formulas preparation. Proper hand hygiene in pre preparation, 
proper asepsis of household items, which must remain distant from other raw foods or without protection, and storage under refrigeration, are some simple, effective and necessary measures to prevent contamination by this agent.

\section{Gene transcription}

The transcriptome analysis is very important to understanding the behavior of Campylobacter spp. under several environmental conditions. The number of studies that addresses the determination of environmental effects on virulence and transcription of genes in foodborne pathogens has increased over recent years (BERGHOLZ et al., 2009; OLESEN et al., 2009; OLESEN et al., 2010; RIEU et al., 2010), however little is known about the specific parameters for Campylobacter (LIGOWSKA et al., 2011; MA et al., 2009; MELO, 2013; PHONGSISAY et al., 2007; XIE et al., 2011).

The production of transcripts was detected for all the studied genes. The results of RT-PCR performed found a variation in ability to produce transcripts in $c i a B$, dnaJ, $\operatorname{sodB}$ and $p 19$ genes in $C$. jejuni over time in refrigerated storage (Table 3 ).

Table 3. Production of transcripts $(\%)$ of $C$. jejuni recovered from two infant formulations artificially contaminated with $10^{3}$ and $10^{4}$ CFU.mL ${ }^{-1}$.

\begin{tabular}{llllll}
\hline \multirow{2}{*}{ Genes } & \multirow{2}{*}{ Hour } & \multicolumn{2}{c}{ Homemade formula } & \multicolumn{2}{c}{ Commercial formula } \\
\cline { 2 - 6 } & 0 & $10^{3}$ & $10^{4}$ & $10^{3}$ & $10^{4}$ \\
\hline ciaB & 24 & 33,3 & - & - & - \\
& 48 & 33,3 & 100 & - & 66,6 \\
& 0 & - & - & 33,3 & 33,3 \\
\hline dnaJ & 24 & 33,3 & 33,3 & 33,3 & 66,6 \\
& 48 & 33,3 & 66,6 & 66,6 & 66,6 \\
& 0 & - & - & 100 & 100 \\
\hline$p 19$ & 24 & - & - & - & 33,3 \\
& 48 & - & - & - & 33,3 \\
\hline $\operatorname{sodB}$ & 0 & - & - & - & - \\
& 24 & - & - & - & 33,3 \\
& 48 & - & & - & 33,3 \\
\hline
\end{tabular}

(-) No production of transcripts.

In general, gene transcription increased with cold storage. The low production of transcripts at time 0 (immediately after inoculation) may be related to a period of the agent adaptation to the new environment.

The ability of Campylobacter to change their transcriptome is associated with the development of a specific mechanisms repertoire that allows rapid metabolic adaptation, as well as changes in growth and behavior in different environments that ensures their survival under stress conditions (LODGE, 2007). Thus, the bacteria regulates gene expression in response to cold shock, heat, and their invasive potential, in order to adapt, survive and, eventually, replicate in these diverse temperatures (STINTZI; WHITWORTH, 2003).

The transcription was most evident in samples inoculated with $10^{4} \mathrm{CFU} / \mathrm{mL}$ of $C$. jejuni $(\mathrm{p}=0,0052-$ Test $T$ paired $)$. Thus, it is likely that a higher number of the microorganism cells favors in the transcription process. According to Guerry (2007) and Lodge (2007), larger quantities of
Campylobacter inoculum can favor the proteins codification that assist in the maintenance and expression of virulence characteristics, as is the case of FlaA protein (motility) and CadF (colonization).

Regarding the formulations, the transcription of genes for adaptation to stress conditions (dnaJ, p19 and sodB) was more evident in strains recovered from commercial formula, but this difference was not significant $(\mathrm{p}=0,250$ Wilcoxon Test). Furthermore, the reduction in large number proportions of viable $C$. jejuni cells in these formulations (Table 2) indicates that in this food matrix, the bacteria had become more injured. Therefore, the different conditions that regulates bacterial transcriptome, signaled to the need to transcribe genes that allows their better adaptation to injury and, hence, their survival. Poli et al. (2012) stated that $C$. jejuni can take various properties to modulate its transcriptome, depending on the situation that is submitted, having many alternatives to deal with stress. 
Mackichan et al. (2004) identified in $C$. jejuni the existence of a serie of signal transduction which may contribute to bacterial adaptation systems. Several profiles of transcription in $C$. jejuni maintained under a variety of growing conditions, indicates considerable variation in gene expression (HENDRIXSON, 2006; MOURIK, 2011; WÖSTEN et al., 2006; WÖSTEN et al., 2010), supporting the idea that the regulation of genes is essential for maintaining the survival of $C$. jejuni.

The presence of prebiotics and vegetable oils in commercial formulas may have contributed indirectly to the injury of $C$. jejuni. According to Winslow (2005), prebiotics are non-digestible food components that benefits the host by stimulating selectively the growth or activity of desirable bacteria population in the colon. Additionally, the prebiotic after probiotic fermentation process results in the production of metabolites, such as organic acids, which may inhibit the growth of some pathogens, providing additional benefits to the host health. Moreover, vegetable oils, present in the composition of commercial formula are recognized for their antimicrobial properties against spoilage and/or pathogenic bacteria (PIRES; PICCOLI, 2012), as the action of carnosic acid, quercetin and allicin to inhibit the growth of Campylobacter (GUTIÉRREZ-DEL-RÍO et al., 2018).

As for homemade formula, no transcription for genes related to environmental adaptation ( $p 19$ and $\operatorname{sod} B$ ) by $C$. jejuni and can be observed smaller percentages of dnaJ transcripts compared to the commercial formula. Thus, it is inferred that the conditions of injury (thermal and oxidative stress) were lower in this food matrix and does not need greater energy expenditure for the transcription of these genes. It is possible that the semisolid consistency of homemade formula may have provided microaerophilic conditions, similar to what happens when the microorganisms are inoculated in thioglycolate, favoring its viability. Mourik (2011) stated that in Campylobacter gene transcription is regulated to prevent the unnecessary production. Thus, the bacteria did not need to use adaptive mechanisms to ensure its survival.

Furthermore, the use of pasteurized milk in the preparation of homemade formula may also have contributed to the survival and lower transcription of genes adaption, since this nutrient plays a role in cell protection. The protective effect of milk may be related to its action in stabilizing the cell membrane fluidity and the contribution of calcium in cellular enzyme stability (CARVALHO et al., 2001).
Conversely, the production of transcripts associated with invasion process ( $c i a B)$ was higher in $C$. jejuni maintained in homemade formula. This genetic information shows that, probably, the agent priority in this case was to adapt itself to colonize and cause disease, and no more, to ensure their survival. Therefore, $C$. jejuni showed a higher pathogenic potential when kept in this array.

The $c i a B$ is an essential gene for encoding $\mathrm{CiaB}$ protein, that is important in the invasion process of epithelial cells (POLI; GUERRY, 2008) and intestinal mucosa (KONKEL et al., 1999; ZIPRIN et al., 2001) The dnaJ gene encodes a heat shock protein, which guarantees thermotolerance, and thus the microorganism is able to overcome the abrupt temperature variations, being able to survive due to the adaptation (STINTZI, 2003).

The $\operatorname{sod} B$ and $p 19$ genes also have direct correlation with the adaption mechanisms of $C$. jejuni. The translation of $\operatorname{sod} B$ protein triggers a defense mechanism of the cell against oxidativestress, due to cold shock. Moreover, this gene specifically protects the cellular components, including various cytoplasmic enzymes, DNA, and factors of membrane, against damage caused by oxygen free radicals (STINTZI; WHITWORTH, 2003). The p19 gene encodes an iron-dependent periplasmic protein whose function is to transport iron (PALYADA et al., 2004) and the regulation of this protein indicates a way to control the level of intracellular iron during stress (BIRK et al., 2012).

\section{CONCLUSIONS}

The viability of $C$. jejuni in two infant formulas for up to 48 hours, even under refrigeration, which is a condition of injury, demonstrates that this agent uses devices that ensure their survival in this milk matrix. However, the cold storage was able to reduce the counts of Campylobacter jejuni in the studied infant milk formulas.

The highest production of virulence transcripts $(c i a B)$ in homemade formulas and the adaptation to stress (dnaJ, p19 and $\operatorname{sodB}$ ) in commercial formulations indicates that transcription by $C$. jejuni is regulated by different mechanisms related priority for their survival. The homemade formula provides the best condition for the agent survival, and thus, allows transcription of the gene related to virulence and has greater importance to public health.

\section{CONFLICTS OF INTEREST}

No conflicts exist. 


\section{Funding statement}

The study was financed by the FAPEMIG

(MG Foundation for Research Support) program, under number PPM-00313-15.

\section{ACKNOWLEDGEMENTS}

To FAPEMIG, CAPES and CNPq for financial support.

RESUMO: Este estudo simulou a contaminação de duas variedades de fórmulas de leite infantil com Campylobacter jejuni (caseiras e comerciais), que foram mantidas sob refrigeração $\left(4-7^{\circ} \mathrm{C}\right)$ por até 48 horas. O objetivo do estudo foi verificar a manutenção da viabilidade e capacidade de produzir transcritos de virulência e resistência a condições de estresse durante os períodos de 0 (após preparação), 24 e 48 horas. C. jejuni permaneceu viável durante todas as etapas analisadas e a presença de coliformes não foi detectada. Em geral, as contagens reduziram 1 ciclo log após 48 horas para todas as amostras, exceto o inóculo de $10^{4} \mathrm{CFU} / \mathrm{mL}$ na fórmula comercial, que reduziu 2 ciclos logarítmicos, indicando maior lesão de $C$. jejuni nesta matriz alimentar. C. jejuni mostrou-se mais adaptado à matriz popular, devido à alta transcrição do gene relacionado à invasão celular, $c i a B$, e mais suscetível na matriz comercial, devido à alta transcrição de genes relacionados a tolerância a condições de estresse (dnaJ, p19, sodB). A baixa dose infectante de $C$. jejuni, juntamente com maior vulnerabilidade de crianças menores de cinco anos, indicam a necessidade de cuidados na preparação e manutenção de fórmulas infantis, para prevenir o uso de matéria-prima contaminada e contaminação cruzada, especialmente em formulações caseiras.

PALAVRAS-CHAVE: Campilobacteriose. Lactentes. Gastroenterite.

\section{REFERENCES}

ASSUNÇÃO, R. M. A. Enterobacter sakazakii em fórmulas lácteas infantis em pó: implementação da metodologia de detecção e avaliação microbiológica de amostras comercializadas no distrito de Lisboa. 2008. 104f. Master Degree Dissertation. Faculdade de Medicina Veterinária, Universidade Técnica de Lisboa, Lisboa, 2008.

BERGHOLZ, T. M.; VANAJA, S. K.; WHITTAM T. S. Gene expression induced in Escherichia coli O157:H7 upon exposure to model apple juice. Applied and Environmental Microbiology, v. 75, n. 11, p. 3542-3553, 2009. https://doi.org/10.1128/AEM.02841-08

BIRK, T.; WIK, M. T.; LAMETSCH, R.; KNOCHEL, S. Acid stress response and protein induction in Campylobacter jejuni isolates with different acid tolerance. BioMed Central Microbiology, v. 12, n. 174, 2012. https://doi.org/10.1186/1471-2180-12-174

BRASIL. (2001). Agência Nacional de Vigilância Sanitária (ANVISA). Resolução RDC nº 12, de 2 de janeiro de 2001. Regulamento Técnico sobre Padrões Microbiológicos para Alimentos. Diário Oficial da União. Brasília/DF. Seção 1.

CARDOSO, M. O que representam os suínos na transmissão de zoonoses para humanos? Acta Scientiae Veterinariae, v. 37, n. 1, p. 81-89, 2009.

CARVALHO, A. C.; RUIZ-PALACIOS, G. M.; RAMOS-CERVANTES, P.; CERVANTES, L. E.; JIANG, X.; PICKERING, L. K. Molecular characterization of invasive and noninvasive Campylobacter jejuni and Campylobacter coli isolates. Journal of Clinical Microbiology, v. 39, n. 4, p. 1353-1359, 2001. https://doi.org/10.1128/JCM.39.4.1353-1359.2001

CIDCN (Committee on Infectious Diseases, Committee on Nutrition). Consumption of Raw or unpasteurized Milk and Milk Products by Pregnant Women and Children. Pediatrics, 133 (1), 175-179, 2014. https://doi.org/10.1542/peds.2013-3502 
EFSA (European Food Safety Authority). The European Union Summary Report on Trends and Sources of Zoonoses, Zoonotic Agents and Food-borne Outbreaks in 2011. EFSA Journal, p. 11, n. 4, p. 213-215, 2013. https://doi.org/10.2903/j.efsa.2013.3129

EIDEH, A. M. F.; AL-QADIRI, H. M. Effect of refrigerated and frozen storage on the survival of Campylobacter jejuni in cooked chicken meat breast. Journal of Food Science, v. 76, n. 1, p.17-21, 2011. https://doi.org/10.1111/j.1750-3841.2010.01924.x

EL-SHIBINY, A.; CONNERTON, A.; CONNERTON, I. Survival at refrigeration and freezing temperatures of Campylobacter coli and $C$. jejuni on chicken skin applied as axenic and mixed inoculums. International Journal of Food Microbiology, v. 131, p. 197-202, 2009. https://doi.org/10.1016/j.ijfoodmicro.2009.02.024

ESTEVES, W. T. C.; FERREIRA, A. P.; SICILIANO, S. Potencial impacto na Saúde Pública por Campylobacter spp. Estudo de caso: curso inferior do Rio São João, RJ, Brasil. Caderno Saúde Coletiva, v. 19, n. 1, p. 74-81, 2011.

GARÉNAUX, A.; JUGIAU, F.; RAMA, F.; DE JONGE, R.; DENIS, M.; FEDERIGUI, M.; RITZ, M. Survival of Campylobacter jejuni strains from different origins under oxidative stress conditions: effect of temperature. Current Microbiology, v. 56, p. 293-297, 2008. https://doi.org/10.1007/s00284-007-9082-8

GODOI, H. S.; GANDRA, T. K. V.; GANDRA, E. A. Campylobacter spp em alimentos - revisão. Arquivo de Ciências Veterinárias e Zoologia da UNIPAR, v.13, n.1, p. 37-41, 2010.

GUERRY, P. Campylobacter flagella: not just for motility - Review. Trends in Microbiology, v. 15, n. 10, p. 456-461, 2007. https://doi.org/10.1016/j.tim.2007.09.006

HADDAD, N.; BURNS, C. M.; BOLLA, J. M.; PRE`VOST, H.; FE`DE`RIGHI, M.; DRIDER, D.; CAPPELIER, J. M. Long-term survival of Campylobacter jejuni at low temperatures is dependent on polynucleotide phosphorylase activity. Applied and Environmental Microbiology, v. 75, n. 23, p. 7310-7318, 2009. https://doi.org/10.1128/AEM.01366-09

HARMON, K. M.; RAMSOM, G. M.; WESLEY, I. V. Differentiation of Campylobacter jejuni and Campylobacter coli by polymerase chain reaction. Molecular and Cellular Probes, v. 11, p. 195-200, 1997. https://doi.org/10.1006/mcpr.1997.0104

HENDRIXSON, D. R. A phase-variable mechanism controlling the Campylobacter jejuni FlgR response regulator influences commensalism. Molecular Microbiology, v. 61 n. 6, p. 1646-1659, 2006.

https://doi.org/10.1111/j.1365-2958.2006.05336.x

ISO 2006. 10272-1: Microbiology of food and animal feeding stuffs - horizontal method for detection and enumeration of Campylobacter spp. Part 1. Detection method. International Standards Organization. ISO 10272-1: 2006.

IVANOVIC, S. Campylobacter as a cause of gastroenteritis in humans and animals. African Journal of Microbiology Research, v. 6, n. 8, p. 1651-1657, 2012. https://doi.org/10.5897/AJMR11.1094

KONKEL, M. E.; KIM, B. J.; RIVERA-AMILL, V.; GARVIS, S. G. Bacterial secreted proteins are required for the internalization of Campylobacter jejuni into cultured mammalian cells. Molecular Microbiology, v. 32, n. 4, p. 691-701, 1999. https://doi.org/10.1046/j.1365-2958.1999.01376.x

LI, Y. P.; INGMER, H.; MADSEN, M.; BANG, D. D. Cytokine responses in primary chicken embryo intestinal cells infected with Campylobacter jejuni strains of human and chicken origin and the expression of bacterial virulence-associated genes. BMC Microbiology, v. 8, n. 107, p. 1-10, 2008.

https://doi.org/10.1186/1471-2180-8-107 
LIGOWSKA, M.; COHN, M. T.; STABLER, R. A.; WREN, B. W.; BRONDSTED, L. Effect of chicken meat environment on gene expression of Campylobacter jejuni and its relevance to survival in food. International Journal of Food Microbiology, v. 145, n. 1, p. S111-S115, 2011. https://doi.org/10.1016/j.ijfoodmicro.2010.08.027

LINHARES, Ingrid Werneck. Avaliação das condições higiênico-sanitárias no preparo de fórmulas infantis em lactário hospitalar. 2012. 118f. Master Degree Dissertation, Faculdade de Farmácia da Universidade Federal de Minas Gerais, Belo Horizonte, Minas Gerais, 2012.

LODGE, K. B. A molecular investigation of Campylobacter jejuni pathogenesis. 2007. 345f. PhD Thesis. School of Applied Sciences Portfolio of Science, Engineering and Technology RMIT University, 2007.

MA, Y.; HANNING, I.; SLAVIK, M. Stress-induced adaptive tolerance response and virulence gene expression in Campylobacter jejuni. Journal of Food Safety, v. 29, n. 1, p. 126-143, 2009.

https://doi.org/10.1111/j.1745-4565.2008.00147.x

MACKICHAN, J. K.; GAYNOR, E. C.; CHANG, C.; CAWTHRAW, S.; NEWELL, D. G.; MILLER, J. F.; FALKOW, S. The Campylobacter jejuni dccRS two-component system is required for optimal in vivo colonization but is dispensable for in vitro growth. Molecular Microbiology, v. 54, n. 5, p. 1269-1286, 2004. https://doi.org/10.1111/j.1365-2958.2004.04371.x

MADALOZZO, F. R.; KOETZ, P. R.; SANTOS, L. R.; RODRIGUES, L. B. Campylobacteriose em humanos e o controle de qualidade em produtos de origem aviária. Higiene Alimentar, v. 21, p. 59-63, 2007.

MAHAN, L. K., ESCOTT-STUMP, S. Alimentos, nutrição and dietoterapia. 12. ed. Elsevier, 2010.

MELO, R. T.; NALEVAIKO, P. C.; MENDONÇA, E. P.; BORGES, L. W.; BELETTI, M. E.; ROSSI, D. A. Campylobacter jejuni strains isolated from chicken meat have several factors virulence representing a potential risk to human. Food Control, v. 33, n. 1, p. 227-231, 2013. https://doi.org/10.1016/j.foodcont.2013.02.032

MONTEIRO, G. P.; MELO, R. T. ; NALEVAIKO, P. C. ; MENDONÇA, E. P. ; FONSECA, B. B. ; ROSSI, D. A. . Sobrevivência de Campylobacter jejuni em amostras de leite pasteurizado e UHT artificialmente contaminados e mantidas sob refrigeração. Revista do Instituto Adolfo Lutz, v. 74, p. 280, 2015.

MOURIK, A. V. Host adaptation mechanisms and transcriptional regulation in Campylobacter jejuni. 2011. 152f. PhD thesis - Infection and Immunity Center Utrecht, Universiteit Utrecht, 2011.

MURAOKA, W. T.; ZHANG, Q. Phenotypic and genotypic evidence for L- fucose utilization by Campylobacter jejuni. Journal of Bacteriology, v. 193, n. 5, p. 1065-1075, 2011.

https://doi.org/10.1128/JB.01252-10

OLESEN, I.; THORSEN, L.; JESPERSEN, L. Relative transcription of Listeria monocytogenes virulence genes in liver pates with varying $\mathrm{NaCl}$ content. International Journal of Food Microbiology, v. 141, n. 1, p. S60S68, 2010. https://doi.org/10.1016/j.ijfoodmicro.2010.01.042

OLESEN, I.; VOGENSEN, F. K.; JESPERSEN, L. Gene transcription and virulence potential of Listeria monocytogenes strains after exposure to acidic and $\mathrm{NaCl}$ stresses. Foodborne Pathogens and Disease, v. 6, n. 6, p. 669-679, 2009. https://doi.org/10.1089/fpd.2008.0243

PALYADA, K.; THREADGILL, D.; STINTZI, A. Iron acquisition and regulation in Campylobacter jejuni. Journal of Bacteriology, v. 186, n. 14, p. 4714-4729, 2004. https://doi.org/10.1128/JB.186.14.4714-4729.2004

PHONGSISAY, V.; PERERA, V. N.; FRY, B. N. Expression of the htrB gene is essential for responsiveness of Salmonella typhimurium and Campylobacter jejuni to harsh environments. Microbiology, v. 153, n. 1, p. 254262, 2007. https://doi.org/10.1099/mic.0.29230-0 
PIRES, T. C.; PICCOLI, R. H. Efeito inibitório de óleos essenciais do gênero Citrus sobre o crescimento de micro-organismos. Revista do Instituto Adolfo Lutz, v. 71, n. 2, p. 378-385, 2012.

POLI, V. F. S.; THORSEN, L.; OLESEN, I.; WIK, M. T.; JESPERSEN, L. Differentiation of the virulence potential of Campylobacter jejuni strains by use of gene transcription analysis and a Caco-2 assay.

International Journal of Food Microbiology, v. 155, n. 1-2, p. 60-68, 2012.

https://doi.org/10.1016/j.ijfoodmicro.2012.01.019

POLY, F.; GUERRY, P. Pathogenesis of Campylobacter. Current Opinion in Gastroenterology, v. 24, n. 1, p. 27-31, 2008. https://doi.org/10.1097/MOG.0b013e3282f1dcb1

RIEU, A.; GUZZO, J.; PIVETEAU, P. Sensitivity to acetic acid, ability to colonize abiotic surfaces and virulence potential of Listeria monocytogenes EGD-e after incubation on parsley leaves. Journal of Applied Microbiology, v. 108, n. 2, p. 560-570, 2010. https://doi.org/10.1111/j.1365-2672.2009.04463.x

SILVA, N.; JUNQUEIRA, V. C. A.; SILVEIRA, N. F. A.; TANIWAKI, M. H.; SANTOS, R. F. S.; GOMES, R. A. R. Manual de métodos de análise microbiológica de alimentos. 3. ed. São Paulo: Varela, 2007.

STINTZI, A. Expression profile of Campylobacter jejuni in response to growth temperature variation. Journal of Bacteriology, v. 185, p. 2009-2016, 2003. https://doi.org/10.1128/JB.185.6.2009-2016.2003

STINTZI, A.; WHITWORTH, L. Investigation of the Campylobacter jejuni Cold-Shock Response by Global Transcript. Genome Letters, v. 2, n. 1-2, p. 18-27, 2003.

TRINDADE, A. A.; STURION, G. L.; PORTO, E. Avaliação do nível de adequação às boas práticas de fabricação de um lactário hospitalar. Higiene Alimentar, v. 23, p. 48-54, 2009.

WHO (World Health Organization). The global strategy for infant and young child feeding, 2004. Available in: http://www.who.int/nutrition/publications/gs_infant_feeding_text_eng.pdf. Access in: apr. 20, 2013.

WHO (World Health Organization). The global view of campylobacteriosis. Utrecht, Netherlands, 9-11, 2012.

WINSLOW, T. Probióticos, prebióticos e simbióticos. In Funcionais and Nutracêuticos (p. 55-62), 2005.

WÖSTEN, M. M.; PARKER, C. T.; VAN MOURIK, A.; GUILHABERT, M. R.; VAN DIJK, L.; VAN PUTTEN, J. P. The Campylobacter jejuni PhosS/PhosR operon represents a non-classical phosphatesensitive two-component system. Molecular Microbiology, v. 62, n. 1, p. 278-291, 2006.

https://doi.org/10.1111/j.1365-2958.2006.05372.x

WÖSTEN, M. M.; VAN DIJK, L.; PARKER, C. T.; GUILHABERT, M. R.; VAN DER MEER-JANSSEN, Y. P.; WAGENAAR, J. A.; VAN PUTTEN, J. P. Growth phasedependent activation of the DccRS regulon of Campylobacter jejuni. Journal of Bacteriology, v. 192, n. 11, p. 2729-2736, 2010.

https://doi.org/10.1128/JB.00024-10

XIE, Y. P.; HE, Y. P.; IRWIN, P. L.; JIN, T.; SHI X. M. Antibacterial activity andmechanism of action of zinc oxide nanoparticles against Campylobacter jejuni. Applied and Environmental Microbiology, v. 77, n. 7, p. 2325-2331, 2011. https://doi.org/10.1128/AEM.02149-10

ZIPRIN, R. L.; YOUNG, C. R.; BYRD, J. A.; STANKER, L. H.; HUME, M. E.; GRAY, S. A.; KIM, B. J.; KONKEL, M. E. Role of Campylobacter jejuni potential virulence genes in cecal colonization. Avian Diseases, v. 45, n. 3, p. 549-557, 2001. https://doi.org/10.2307/1592894 